\title{
Student Facilitated PBL - A Capstone Collaborative Learning Experience in the Griffith University MBBS Program
}

\author{
doi:10.3991/ijet.v6i1.1433 \\ Heather Alexander, Raymond Tedman, Barbara Wallace and Helen Pountney \\ School of Medicine, Griffith University
}

\begin{abstract}
We report on an innovation in teaching and learning designed to extend the collaborative learning of PBL, that occurs during the first two years of a four year graduate entry medical program, to a capstone learning experience to assist the transition to a hospital based year 3. During the last five weeks of Year 2 the PBL sessions consist of an initial student facilitated session early in the week followed by a large format session for the entire class convened by two clinicians. The new format PBL was perceived positively by the students and staff involved and may have advantages over traditional formats in developing students' clinical reasoning and differential diagnosis skills.
\end{abstract}

Index Terms-collaborative learning, student facilitated $P B L$, capstone experience, medicine

\section{INTRODUCTION}

Medical students undergo a significant transition in learning when they move from the early years of a medical program, where learning takes place within a medical school, to the later years of their program where learning is based in the clinical environment. Medical programs using Problem-Based Learning (PBL) curricula in the early years of the program often find PBL challenging to implement in the later years when students are located within the clinical environment and consider alternate formats [1-3]. Schools are beginning to consider the use of transitional instruction to assist the students to make this change [4]. We report on an innovative new format of PBL at the end of the second year of a 4 year medical program, designed to assist students with this transition to the clinical learning environment.

The graduate-entry MBBS program at the Griffith University School of Medicine received its first cohort of students in January, 2005. This integrated curriculum uses a hybrid PBL and lecture-based approach combining the latest developments in information technology, state-ofthe-art, purpose-built facilities and curriculum innovations where students begin their clinical skills activities in semester 1 of Year 1. Careful consideration is given to ensuring a good balance of gender, background and previous studies, when placing students into PBL groups. Students are placed into new groups at the beginning of each year and half way through the year. Griffith University has licensed the clinical scenarios, curriculum documentation and associated resources from the Flinders University Medical Program as the framework for its medical curriculum, but over a period of six years the Flinders curriculum has been reviewed, updated and redesigned for on-line delivery using a totally new electronic delivery, communication and evaluation system which has been designed to incorporate the underpinning cognitive principles surrounding the PBL cases [5]. Part of this redesign has been the development of a new approach to PBL in the latter part of the second year of the program, specifically designed to further develop clinical reasoning skills and to improve the transition to full time clinical exposure in Years 3 and 4.

Problem-Based Learning is a well documented method of interactive learning that is being progressively incorporated into medical curricula throughout the world, including Australia [6-8]. The PBL process involves students working in small groups, two or three times a week, with a tutor who has a role of facilitator rather than a provider of content. The learning focuses on patient problems as a context for students to acquire problem-solving skills and knowledge about the basic and clinical sciences $[9,10]$. Students work through a process that incorporates discussion of possible hypotheses, development of strategies to test the hypotheses, collection and analysis of new information, determination of the gaps in their knowledge and understanding and finally establishment of learning goals that direct their independent learning outside the PBL tutorials [11].

Research into the effectiveness of PBL curricula has emphasised small but significant effects on clinical reasoning and diagnostic abilities, plus improvements in satisfaction [12-14], psychosocial knowledge, humanistic attitudes [15] and various professional competencies [16]. However, conclusions by Colliver [17], that there is no convincing evidence that PBL improves knowledge bases and clinical performance of medical students have been criticised in more recent papers by Norman and Schmidt [14] and Albanese [18]. In a survey of graduates from a problem-based and a conventional medical school, Schmidt, Vermeulen and van der Molen [16] concluded that PBL not only has positive effects on interpersonal skills, problem solving skills and self directed learning but also positively affected work-related skills such as productivity, planning skills and ability to work under pressure. Recently, Koh et al [19] conducted a systematic review of evidence of effects that PBL during medical school had on physician competencies after graduation. They concluded that the positive effects after graduation were mainly social and cognitive in nature.

Clinical reasoning skills and diagnostic abilities are important skills that medical students develop throughout all years of their programs. Bowen [20] focuses on how 
teachers during the clinical years can facilitate the learning process to help learners make the transition from being diagnostic novices to becoming expert clinicians. Among the various educational strategies that can be promoted to help develop clinical diagnostic reasoning, Bowen emphasised the importance of requiring students to prioritise lists of diagnostic possibilities and explain justifications to help them create links between clinical findings and relevant diagnoses, thereby bolstering their ability to develop illness scripts.

Teaching throughout the first two years of the MBBS curriculum at Griffith University is organised into system blocks ranging from 4 to 12 weeks duration. By the time the students begin their last block, called the Integration Block, which runs for 10 weeks at the end of the second year, they have studied all body systems. The Integration Block emphasises the integration of basic science and clinical knowledge from the previous systems units using PBL cases based on multi-system illnesses. It also introduces a greater focus on management and treatment as well as investigation of underlying mechanisms and causes of disease. It aims to increase student awareness of team roles and hospital/ community resources, and to further develop clinical reasoning skills prior to entering Year 3 where Case-Based Learning (CBL) is utilised.

The new PBL format was initially introduced into the last four weeks of Year 2 in 2006. In subsequent years this was increased to five weeks. As in other medical programs, Case-Based Learning in Year 3 runs with a tutorless group for the first tutorial in the week, followed by an expert led tutorial at the end of the week and utilises real patient cases as the stimulus for learning. The goal of the new format PBL were to facilitate the transition to $\mathrm{CBL}$ in Year 3, while allowing further development of the students' clinical reasoning and differential diagnosis skills and in justifying those to consultants. This paper reports the student perceptions of this curriculum change.

\section{METHODS}

\section{A. The new PBL format}

This PBL format included two tutorial sessions per week. Tutorial 1, which was held each Tuesday, involved the students working through the case in their usual PBL groups and using the standard PBL approach, but without a staff tutor. Student-identified learning issues were recorded online throughout the tutorial. The final session (Tutorial 2), held on Friday each week, was an interactive session for the entire cohort. At this final session, a group of up to three clinicians led the session and emphasised clinical reasoning processes and the students' training in differential diagnosis.

For this new format, new cases were designed in consultation with specialists at the Gold Coast Hospital (4 in 2006; 5 new cases each year in 2007, 2008 and 2009). These cases were deliberately selected to be of undifferentiated presentations, with differential diagnoses that could involve multiple body systems. Table I shows the list of cases used in the first year that this new format was introduced.

No information related to the cases, such as titles of supporting lectures or case readings, was available to the students on-line before the case commenced. As the initial presentations were also undifferentiated, this meant that
TABLE I.

BRIEF DESCRIPTIONS OF THE FIRST FOUR CASES USED WITH THE NEW PBL FORMAT IN 2006

\begin{tabular}{|l|l|}
\hline \multicolumn{1}{|c|}{ Case } & \multicolumn{1}{c|}{ Description } \\
\hline $\begin{array}{l}\text { Shortness of } \\
\text { breath }\end{array}$ & $\begin{array}{l}\text { A 70-year-old woman presents to the Emergency } \\
\text { Department with the clinical problem of shortness of } \\
\text { breath. It will illustrate the uncertainty that clinicians } \\
\text { face in deciding an appropriate approach to clinical } \\
\text { uncertainty and multiple possible simultaneous } \\
\text { pathologies. }\end{array}$ \\
\hline $\begin{array}{l}\text { Case 2 } \\
\text { Sick child }\end{array}$ & $\begin{array}{l}\text { An 18-month-old child presents with a fever. She } \\
\text { has no rash, is non-immunised and attends day care. } \\
\text { The case involves developing a plan for the investi- } \\
\text { gation of a child with a fever of unknown origin. } \\
\text { With the case information provided, the students } \\
\text { should recognise that the child is very unwell and } \\
\text { requires a lumbar puncture as part of her initial } \\
\text { work-up. }\end{array}$ \\
\hline $\begin{array}{l}\text { Case 3 } \\
\text { pain }\end{array}$ & $\begin{array}{l}\text { A 23-year-old female university student presents to } \\
\text { the Emergency Department with a } 5 \text { day history of } \\
\text { abdominal pain associated with loose bowel mo- } \\
\text { tions. The case concentrates on the broad causes for } \\
\text { and the principles of assessment for abdominal pain. } \\
\text { The students are steered to consider both a gastroen- } \\
\text { terologic and gynaecologic origin for this pain. }\end{array}$ \\
\hline $\begin{array}{l}\text { Case 4 } \\
\text { and diabetes }\end{array}$ & $\begin{array}{l}\text { A 55-year-old obese man presents to his General } \\
\text { Practitioner complaining of the vague symptoms of } \\
\text { tiredness and breathlessness on exertion. He is found } \\
\text { to have significant renal disease and diabetes com- } \\
\text { plicated by his smoking, obesity and alcohol intake. } \\
\text { The students are encouraged to review the renal, } \\
\text { cardiovascular, endocrine and vascular systems of } \\
\text { the body to prompt them to a differential diagnosis } \\
\text { of renal disease and diabetes. }\end{array}$ \\
\hline
\end{tabular}

the students had to start the cases without any prompts as to the likely body system/s involved. During Tutorial 1 , the students were required to submit, in writing, a single group response at designated places throughout the tutorial to indicate:

- What they would ask about on taking a history

- What they would look for on examination

- What investigations they would do (if appropriate to the case)

- Their differential diagnosis

- Their admission notes for this patient.

These submissions were summarised by School staff, to provide the clinicians with a quick overview of which aspects were or were not elicited, which aspects on physical examination were or were not listed and which differential diagnoses were provided by each group. These summaries were provided in advance to the clinicians participating in the Friday large-group session and assisted their preparation for this tutorial. At that session, the clinicians questioned the students, who were seated in their PBL groups in the lecture theatre, as to the reasoning behind their submitted decisions, and also took the students through how they, as an experienced clinician, would approach this same case.

\section{B. The evaluation instrument}

An evaluation instrument, conducted at the end of the Integration Block for each cohort of Year 2 students from 2006 to 2009, was designed to see if this new format of PBL was perceived to have achieved its goals, to rate student enjoyment and to gather student opinion as to 


\section{StUdent FACILITATED PBL - A CAPSTONE COLLABORATIVE LEARNING EXPERIENCE IN THE GRIFFITH UNIVERSITY MBBS PROGRAM}

whether this new format should be used more extensively in the program. The survey instrument included Likert item statements (see Table 3) and questions eliciting free text responses. All students in Year 2 participated in this curriculum change (2006: $\mathrm{n}=80$, number of PBL groups $=$ 10; 2007: $\mathrm{n}=123$, number of PBL groups $=15 ; 2008$ : $\mathrm{n}=148$, number of PBL groups $=17,2009: \mathrm{n}=154$, number of PBL groups $=17$ ).

\section{Data Analysis}

The data were analysed using the SPSS ${ }^{\circledR}$ package, version 16.0. The data demonstrated a non-normal distribution, using skewness, kurtosis and the Shapiro-Wilk test for normality; therefore a non-parametric test (MannWhitney U test) was used to test for differences between groups. The reliability was analysed using Cronbach's alpha.

\section{RESULTS}

\section{A. Likert item statements}

Student cohorts for the Year 2 class increased from 80 in 2006 to 123 in 2007, 148 in 2008 and 154 in 2009 (see Table 2). Four weeks of the integration block were devoted to this new format in 2006, with five weeks in 2007, 2008 and 2009. Fifty-nine, 109, 137 and 115 students responded to the survey (response rate $73.8 \%, 88.6 \%$, $92.5 \%$ and $74.7 \%$ ) for the 2006, 2007, 2008 and 2009 surveys respectively. Cronbach's coefficient alpha increased from .778 in 2006 to .876 in 2009 with an alpha of .847 for all 415 responses over the 2006 to 2009 period.

TABLE II.

INTERNAL CONSISTENCY RELIABILITY OF STUDENT EVALUATIONS

\begin{tabular}{|c|c|c|c|c|c|}
\hline Year & $\begin{array}{c}\mathbf{2 0 0 6 -} \\
\mathbf{2 0 0 9}\end{array}$ & $\mathbf{2 0 0 6}$ & $\mathbf{2 0 0 7}$ & $\mathbf{2 0 0 8}$ & $\mathbf{2 0 0 9}$ \\
\hline $\mathbf{N}$ & 419 & 59 & 108 & 137 & 115 \\
\hline $\begin{array}{c}\text { Response } \\
\text { rate }\end{array}$ & $83.1 \%$ & $73.8 \%$ & $88.6 \%$ & $92.5 \%$ & $74.7 \%$ \\
\hline $\begin{array}{c}\text { Cronbach's } \\
\text { alpha }\end{array}$ & .847 & .778 & .810 & .839 & .876 \\
\hline
\end{tabular}

The responses of students to the Likert item statements are shown in Table 3 . The students were very positive about the new format. The statement relating to the enjoyment of the new format, of tutorless first PBL sessions plus large group final sessions, returned a mean score for all four cohorts of students of 4.37 for a 5 point Likert scale. Ninety-four per cent agreed or strongly agreed that they enjoyed the format (see Table 4).

The success of the new format when it was introduced in 2006 has been maintained. Analysis of the data, using the Mann-Whitney U test, revealed that the responses for all statements except for questions 2, 3, 7 and 8 were not significantly different $(p<.05)$ while the responses for statements 2 (expanding the use of this format for the entire Integration Block), 3 (new format emphasised integration), 7 (new format was useful for emphasising the process of clinical reasoning) and 8 (new format was useful for developing skills in differential diagnosis) increased significantly from 2006 to $2008(\mathrm{p}<.05)$.
TABLE III.

RESPONSES, MEANS AND STANDARD ERRORS (SE) FOR 8 LIKERT ITEM STATEMENTS RELATED TO THE NEW PBL FORMAT FOR YEAR 2 MBBS STUDENTS.

\begin{tabular}{|c|c|c|c|c|c|}
\hline Statements & $\begin{array}{l}\text { Mean } \\
\text { SE) }\end{array}$ & $\begin{array}{l}\text { Mean } \\
(\mathrm{SE})^{2}\end{array}$ & $\begin{array}{l}\text { Mean } \\
\text { SE) }{ }^{3}\end{array}$ & $\begin{array}{l}\text { Mean } \\
(\mathrm{SE})^{4}\end{array}$ & $\begin{array}{l}\text { Mean } \\
\text { (SE) }\end{array}$ \\
\hline $\begin{array}{l}\text { 1. I enjoyed the new format, of } \\
\text { tutorless first PBL sessions plus } \\
\text { large group final sessions. }\end{array}$ & $\begin{array}{l}4.38 \\
.081) \\
\end{array}$ & $\begin{array}{l}4.58 \\
.056)\end{array}$ & $\begin{array}{l}4.14 \\
.058)\end{array}$ & $\begin{array}{l}4.43 \\
.064)\end{array}$ & $\begin{array}{l}4.37 \\
(.033)\end{array}$ \\
\hline $\begin{array}{l}\text { 2. The new format, of tutorless } \\
\text { first PBL sessions plus large } \\
\text { group final sessions, should be } \\
\text { expanded to involve all the Inte- } \\
\text { gration Block cases. }\end{array}$ & 3.41 & $\begin{array}{l}4.06 \\
.089)\end{array}$ & $\begin{array}{l}3.39 \\
.095)\end{array}$ & $\begin{array}{l}3.93 * \\
.101)\end{array}$ & $\begin{array}{l}3.71 \\
(.054)\end{array}$ \\
\hline $\begin{array}{l}\text { 3. The new format of tutorless } \\
\text { first PBL sessions plus large } \\
\text { group final sessions, emphasised } \\
\text { integration across body systems. }\end{array}$ & 3.81 & $\begin{array}{l}4.24 \\
.065)\end{array}$ & $\begin{array}{l}4.00 \\
.059)\end{array}$ & $\begin{array}{l}4.10 * \\
.074)\end{array}$ & $\begin{array}{l}4.06 \\
(.036)\end{array}$ \\
\hline $\begin{array}{l}\text { 4. The new format, of tutorless } \\
\text { first PBL sessions plus large } \\
\text { group final sessions, was more } \\
\text { effective than the conventional } \\
\text { tutor-led PBL tutorials in devel- } \\
\text { oping team-working skills. }\end{array}$ & $\begin{array}{l}3.85 \\
.115) \\
\end{array}$ & $\begin{array}{l}3.95 \\
.086)\end{array}$ & $\begin{array}{l}3.84 \\
.078)\end{array}$ & $\begin{array}{l}4.01 \\
.095\end{array}$ & $\begin{array}{l}3.92 \\
(.046)\end{array}$ \\
\hline $\begin{array}{l}\text { 5. The new format, of tutorless } \\
\text { first PBL sessions plus large } \\
\text { group final sessions, was more } \\
\text { effective than the conventional } \\
\text { tutor-led PBL tutorials in devel- } \\
\text { oping clinical reasoning skills. }\end{array}$ & 3.95 & $\begin{array}{l}4.33 \\
.066)\end{array}$ & $\begin{array}{l}3.91 \\
.068)\end{array}$ & $\begin{array}{l}4.05 \\
.085)\end{array}$ & $\begin{array}{l}4.06 \\
(.039)\end{array}$ \\
\hline $\begin{array}{l}\text { 6. The new format, of tutorless } \\
\text { first PBL sessions plus large } \\
\text { group final sessions, was more } \\
\text { effective than the conventional } \\
\text { tutor-led PBL tutorials in devel- } \\
\text { oping skills in differential diagno- } \\
\text { sis. }\end{array}$ & 4.00 & $\begin{array}{l}4.32 \\
.075)\end{array}$ & $\begin{array}{l}4.14 \\
.065)\end{array}$ & $\begin{array}{l}4.24 \\
.069)\end{array}$ & $\begin{array}{l}4.20 \\
(.038)\end{array}$ \\
\hline $\begin{array}{l}\text { 7. The large group PBL format, } \\
\text { involving clinicians, was useful in } \\
\text { emphasising the process of clini- } \\
\text { cal reasoning }\end{array}$ & $\begin{array}{l}4.22 \\
.084)\end{array}$ & $\begin{array}{l}4.45 \\
.061)\end{array}$ & $\begin{array}{l}4.14 \\
.069)\end{array}$ & $\begin{array}{l}4.42 * \\
.064)\end{array}$ & $\begin{array}{l}4.31 \\
(.035)\end{array}$ \\
\hline $\begin{array}{l}\text { 8. The large group PBL format, } \\
\text { involving clinicians, was useful } \\
\text { for developing skills in differen- } \\
\text { tial diagnosis }\end{array}$ & $\begin{array}{l}4.17 \\
.081)\end{array}$ & $\begin{array}{l}4.42 \\
.070)\end{array}$ & $\begin{array}{l}4.01 \\
.074)\end{array}$ & $\begin{array}{l}4.44 * \\
.067)\end{array}$ & $\begin{array}{l}4.26 \\
(.038)\end{array}$ \\
\hline
\end{tabular}

TABLE IV

RESPONSES (\% AGREE OR STRONGLY AGREE) TO 8 LIKERT ITEM STATEMENTS RELATED TO THE NEW PBL FORMAT FOR YEAR 2 MBBS STUDENTS

\begin{tabular}{|c|c|c|c|c|c|}
\hline \multirow{2}{*}{ Statements } & \multicolumn{5}{|c|}{ Years of survey } \\
\cline { 2 - 7 } & $\mathbf{2 0 0 6}$ & $\mathbf{2 0 0 7}$ & $\mathbf{2 0 0 8}$ & $\mathbf{2 0 0 9}$ & $\begin{array}{c}\mathbf{2 0 0 6} \\
\mathbf{2 0 0 9}\end{array}$ \\
\hline 1 & 94.9 & 96.3 & 92.7 & 92.2 & 94.0 \\
\hline 2 & 47.5 & 73.4 & 48.9 & 66.1 & 59.0 \\
\hline 3. & 74.6 & 87.2 & 84.4 & 80.0 & 81.6 \\
\hline 4 & 69.5 & 72.5 & 71.1 & 75.9 & 72.3 \\
\hline 5 & 79.7 & 91.7 & 75.9 & 79.1 & 81.6 \\
\hline 6 & 76.3 & 89.8 & 86.0 & 85.2 & 84.3 \\
\hline 7 & 91.5 & 91.6 & 86.1 & 93.9 & 90.8 \\
\hline 8 & 91.5 & 90.7 & 81.5 & 92.2 & 89.0 \\
\hline
\end{tabular}




\section{StUdent FACILITATED PBL - A CAPSTONE COLlabORATIVE LEARNING EXPERIENCE IN THE GRIFFITH UNIVERSITY MBBS PROGRAM}

Interestingly, $47.5 \%$ of the 2006 students and $66.1 \%$ of the 2009 students $(59.1 \%$ of all cohorts) agreed or strongly agreed that the use of this new format should be expanded to use earlier in the curriculum (see Table 4). The new format was perceived by students to be more effective than conventional PBL in developing skills in clinical reasoning, differential diagnosis and teamwork $(81.6 \%, 84.3 \%$ and $73.3 \%$ of all respondents either agreeing or strongly agreeing with the statements). Ninety point eight per cent and $89.0 \%$ of all respondents agreed or strongly agreed that the expert-led sessions were useful in emphasising the process of clinical reasoning and in developing skills in differential diagnosis respectively.

\section{B. Comments}

Of the 419 respondents, $167(39.86 \%)$ provided a total of 257 comments (Table 5). The majority of comments $(28.40 \%)$ related to suggestions for improvements, while slightly more than $28.02 \%$ of the comments reflected the positive view that students had about the new format. The clinical relevance of the Friday session was described as excellent/great in $8.95 \%$ of the comments. This was closely followed by $8.17 \%$ of comments suggesting that the new format should be extended to other PBL cases in the curriculum. In 2007 and 2008 there were 5.88\% and $6.32 \%$ of comments respectively where students complained about being "picked on" by clinicians and being made to feel humiliated. This reduced to a single comment out of 80 in 2009. In 2008 there were 6 comments $(6.32 \%)$ complaining that there were too many students in the large group Friday presentations. This type of comment did not appear in any other cohort. Again in 2008, 5 different students did not find the Friday session useful and one also commented that the Friday class size was too large. The percentage of "other" comments decreased from 25.81\% (2006) to $8.75 \%$ (2009).

Twenty three students $(8.95 \%)$ wrote comments about the clinical relevance of the new format and the benefit of the Tutorial 2 expert-led sessions:

- 'Learned a lot more of practical, clinical information'

- 'The sessions with the specialists at the end were fantastic'

- 'I enjoyed the group Friday sessions and discussion'

- 'Really valued the format of the last 4 cases in developing clinical reasoning skills and management plan'

Seven students compared the new format to the standard PBL, and commented on difficulties that arose without a staff tutor present in tutorial 1. These covered five topics:

- '...not as effective for learning outcomes, or going away to report info back'

- 'Sometimes the PBL group got off topic and students became easily distracted'

- 'The dominant became more dominant and the quiet became more quiet'

- 'Tuesday's sessions I didn't fine encouraged group participation'

- 'New format allows for student independence, which is great, but we tend to head down the wrong path occasionally without a tutor'
TABLE V.

COMMENTS DATA FROM YEAR 2 INTEGRATION BLOCK EVALUATION SURVEYS 2006 TO 2009

\begin{tabular}{|c|c|c|c|c|c|}
\hline Year & $\mathbf{2 0 0 6}$ & $\mathbf{2 0 0 7}$ & $\mathbf{2 0 0 8}$ & $\mathbf{2 0 0 9}$ & $\begin{array}{c}\mathbf{2 0 0 6} \\
\mathbf{2 0 0 9}\end{array}$ \\
\hline $\begin{array}{c}\text { Number of respon- } \\
\text { dents }\end{array}$ & 59 & 109 & 138 & 118 & 419 \\
\hline $\begin{array}{c}\text { Response rate (\%) } \\
\text { Respondents who } \\
\text { made comments }\end{array}$ & 73.80 & 88.60 & 92.50 & 74.70 & 83.1 \\
\hline $\begin{array}{c}\text { \% of respondents } \\
\text { who made com- } \\
\text { ments }\end{array}$ & 40.68 & 37.61 & 28.89 & 42.37 & 39.86 \\
\hline $\begin{array}{c}\text { Number of com- } \\
\text { ments }\end{array}$ & 31 & 51 & 95 & 80 & 257 \\
\hline $\begin{array}{c}\text { Comment catego- } \\
\text { ries }\end{array}$ & 0.00 & 5.88 & 6.32 & 1.25 & 3.89 \\
\hline Picked-on & 0.00 & 0.00 & 6.32 & 0.00 & 2.33 \\
\hline $\begin{array}{c}\text { Friday class size too } \\
\text { large }\end{array}$ & 3.23 & 1.96 & 2.11 & 6.25 & 3.50 \\
\hline $\begin{array}{c}\text { Difficulty with no } \\
\text { tutor on Tues }\end{array}$ & 29.03 & 31.37 & $18.95 \%$ & 36.25 & 28.02 \\
\hline $\begin{array}{c}\text { Clinical rele- } \\
\text { vant/information } \\
\text { excellent/great }\end{array}$ & 16.13 & 9.80 & 5.26 & 10.00 & 8.95 \\
\hline Friday too long & 0.00 & 1.96 & 3.16 & 0.00 & 1.56 \\
\hline $\begin{array}{c}\text { Enjoyed or excellent } \\
\text { format }\end{array}$ & 0.00 & 13.73 & 7.37 & 8.75 & 8.17 \\
\hline Extend to more cases & 1.96 & 6.32 & 0.00 & 2.72 \\
\hline $\begin{array}{c}\text { Did not find Friday } \\
\text { class useful }\end{array}$ & 0.00 & 17.65 & 34.74 & 28.75 & 28.40 \\
\hline $\begin{array}{c}\text { Suggested improve- } \\
\text { ments }\end{array}$ & 25.81 & 15.69 & 9.47 & 8.75 & 12.45 \\
\hline Other & 25.81 & & & \\
\hline
\end{tabular}

One student recognised the importance of group skills underlying the success of the student led tutorials:

- 'Really preferred this new format, but I think it all depends on the PBL group itself - cooperation and team working skills'.

Eight students expressed the need for further guidance:

- 'More lectures needed please'

- 'Very broad - difficult to cover all LO's. Not sure of depth required...

- 'More precise learning objectives.........",

Two students highlighted the significance of the lack of cues available to students at the start of the case, to prevent them predicting which body system would be involved:

- 'The format made us work harder but the key was the secrecy of the cases. For it to be successful next year, new list of cases needs to be made each year'

An unexpected outcome was that the students asked many questions during the large-group sessions about junior doctors' roles in the clinical setting and about practical skills associated with working as a clinician in the hospital environment. Student comments also indicated that the new format was a welcome change from the faculty-led PBL sessions characteristic of Year 1 and most of Year 2.

Positive comments were also received anecdotally from the clinicians involved in the Friday large-group sessions about the students' abilities in clinical reasoning and differential diagnosis, their enthusiasm and about the format. School staff, who collected the written submissions from 
each group, noted that the students spent longer in Tutorial 1 , than they had in their previous cases in the block.

\section{DISCUSSION}

When the students began the Integration Block they were still engaging positively with the PBL process following the same format as all previous PBL cases in Years 1 and 2, even though they were only 10 weeks away from finishing Year 2. However, when the students began the new format PBL, five weeks into the Integration Block, there was a markedly improved engagement of the students and an improved level of enthusiasm for PBL that was noticed by staff and reflected in the student comments. The new format was perceived positively by the staff and students (a mean score for all four cohorts of students of 4.37 for a 5 point Likert scale) with $94.0 \%$ agreeing or strongly agreeing that they enjoyed the format. There was no evidence in the student comments that the positive evaluation was due to the prospect of finishing PBL and entering Year 3.

Considerable effort has been put into improving this new format of PBL through responding to student and staff comments. We believe that this underlies the significant improvement in ratings for questions relating to expansion of the new format to involve more cases in the Integration Block, the ability of the new format to emphasise integration across body systems and the usefulness of the large group session in developing skills in differential diagnosis. One of the key goals of introducing this format was to facilitate the students' transition into Year 3 where they would be expected to participate in CBL that included one student-led tutorial each week. Aspects of this new format that support this preparation of students for later years, include the types of presentations in the cases, the lack of cues as to which body systems are involved, and the introduction a student-led Tutorial 1.

Frequently in a PBL curriculum, particularly those of a hybrid nature, details of timetables, resources or lectures, or indeed the title of the block within which the case is located, can provide cues as to the likely body system or mechanisms that underpin the problem or case presentation. This new format presented the students with undifferentiated presentations without these cues, challenging them with a situation that more realistically reflects the nature of clinical practice. Thus the last 10 weeks of Year 2 culminate in an important capstone learning experience that goes beyond the description used by Holdsworth, Watty and Davies [21] as bringing "together the knowledge of an academic discipline and student transition to the world of work".

Studies of student-led tutorials (SLT) in problem-based learning have reported that there is no difference in examination scores between SLT and faculty led tutorials (FLT) $[22,23]$. Student tutors were perceived to be better in providing feedback as well as understanding the difficulties faced by students than faculty tutors and SLT groups were better in decision making and displayed better support for the group leader compared to faculty-led tutorials (FLT) [23]. These authors also noted that SLT groups had difficulties in analysis of problems presented in the first session. This may have been due to the habit of students in student facilitated groups of taking short cuts in the PBL process [22]. This might in turn undermine some of the goals of PBL e.g. to develop more complex and sophisticated problem-solving skills [22]. Seven students in this study commented on difficulties they experienced during the first, student facilitated tutorial. One student recognised that the success of the student facilitated tutorials was dependent on 'cooperation and team working skills'.

In a study of small group PBL versus large group PBL for a unit of study in the cardiovascular system, Roberts et al [24] reported no significant differences in learning outcomes as measured by pre- and post-knowledge tests, student educational effectiveness questionnaire and assessment of student group work and presentations. The students preferred the small group PBL, but they suggested that the large group format, supported with e-learning techniques, might be a useful alternative approach to PBL, especially when faced with resource limitations [24]. In the present study, the students enjoyed the new format and their overall ratings of their experience were very positive. While the majority of the 2007 class and the 2009 class were in favour of extending the new format to other cases, the majority of students in the 2006 and 2008 classes did not agree that the use of the new format should be expanded in the curriculum. Some students thought it would be good to have the new format throughout Year 2 while others suggested a mix of both formats throughout Years 1 and 2. We would thus caution the use of adopting this format earlier in a medical program when the students may not be ready for the new format and may not possess the required level of independence from faculty tutors.

The new format of PBL was feasible to deliver and reduced tutor costs considerably, although clinicians were still required for Tutorial 2. Staff time was also required to develop summaries of the information from students, to facilitate the clinicians' preparation for Tutorial 2 each week. The latter could be reduced through greater use of the online delivery system by incorporating small changes to capture and prepare summaries of student on-line responses. In addition, it is vital for the continued success of this new PBL format that new cases are written every year. The "educational rationale for the PBL process is predicated on students encountering novel situations and adapting their reasoning processes as they grapple with the complexities of a case" [25]. PBL cases need to be updated and rewritten, if they are to continue to assist the development of clinical reasoning skills [26].

The new format of PBL may have advantages over traditional formats in developing students' clinical reasoning and differential diagnosis skills and in asking students to justify these to experienced clinicians. To assist in the development of students' clinical reasoning, Bowen [20] highlights the need for teachers to demonstrate their reasoning, including highly discriminating features clinicians seek in history and physical findings, and for asking learners to prioritise diagnostic possibilities and to explain their justifications. This new format addresses both of these directions during the expert-led tutorial 2. During this tutorial, clinicians questioned student groups on their reasoning and justification, and also explained what they would see as important features as they worked through the case. The fact that all groups provided their lists of reasonable differential diagnoses to the clinicians demonstrates their ability to work together as a group without a staff tutor, which will be required of students in later years of the program. Macallan et al [3] reported positive student involvement with a model of clinical problem based 


\section{StUdent FACILITATEd PBL - A CAPSTONe Collaborative LEARning EXPERIENCE IN THE GRIFFith University MBBS PROGRAM}

learning that was trialled during clinical attachments for third year medical students. In this model, a tutor acted primarily as a facilitator in the first tutorial but took on the role of expert rather than facilitator in the second tutorial a few days later. The students in this trial discussed history taking and examination in the context of differential diagnosis and learning objectives associated with clinical skills, disease mechanisms and clinical management. This is very much what we train our first and second year students to do in their regular PBL sessions but which is further developed through the expert-led large group PBL sessions described in our paper. Macallan et al [3] also concluded that key elements in the success of this approach included the involvement of expert tutors and a non-threatening learning environment. This is reflected in some of the student comments in our evaluation surveys. While it is important that students be questioned about their reasoning it becomes counterproductive if the questioning is interpreted by some students as a form of harassment.

One of the unexpected outcomes of the new format was that students, despite attending hospitals regularly since semester 2 of Year 1 of the program, questioned the clinicians during tutorial 2 about various practical aspects of functioning as a junior doctor in the hospital environment. Dornan et al [27] have suggested that learners build professional identity through social interaction with practitioner peers and patients. We suggest that this aspect of the new format may be valuable as students are preparing to move into clinical settings.

\section{CONCLUSION}

This evaluation study has shown that the new format of PBL is a useful method to consider for limited use as a capstone learning experience, preparing students for learning in the clinical environment

\section{ACKNOWLEDGEMENTS}

The authors thank the clinicians from the Gold Coast and John Flynn Hospitals who helped design the cases and participated in the large group sessions, especially $\mathrm{P}$ Bowe, B Bonecki, N Buckmaster, P Davoren, S Maloney and G Ostapovich. We also thank Mr Robert Loudon for his helpful comments regarding the manuscript.

\section{REFERENCES}

R. Harden, J. Crosby, M. Davis, P. Howie, and A. Struthers, "Task-based learning: the answer to integration and problem-based learning in the clinical years," Medical Education, vol. 34, pp. 391-397, 2000.

[2] G. Ryan, T. Dolling, and S. Barnet, "Supporting the problembased learning process in the clinical years: evaluation of an online Clinical Reasoning Guide," Medical Education, vol. 38, pp. 638$645,2004$.

[3] D. C. Macallan, A. Kent, S. C. Holmes, E. A. Farmer, and P. McCrorie, "A model of clinical problem-based learning for clinical attachments in medicine," Medical Education, vol. 43, pp. 799807, 2009.

[4] E. van Gessel, M. Nendaz, B. Vermeulen, A. Junod, and N. Vu, "Development of clinical reasoning from the basic sciences to the clerkships: a longitudinal assessment of medical students' needs and self-perception after a transitional learning unit," Medical Education, vol. 37, pp. 966-974, 2003.

[5] R. A. Tedman, H. Alexander, and R. Loudon, "Problem-based learning in an e-learning environment: a case study at Griffith University School of Medicine," in Evolution of Teaching and
Learning Paradigms in Intelligent Environment, C. J. Jain, R. A. Tedman, and D. K. Tedman, Eds. Berlin: Springer-Verlag, 2007, pp. 31-46.

[6] G. Maudsley, "Do we all mean the same thing by "problem-based learning"? A review of the concepts an a formulation of the ground rules," Academic Medicine, vol. 74, pp. 179-185, 1999.

[7] P. Smits, J. Verbeek, and C. de Buisonj'e, "Problem based learning in continuing medical education: a review of controlled evaluation studies," British Medical Journal, vol. 324, pp. 153-156, 2002.

[8] F. W. Wood, "ABC of learning and teaching in medicine," British Medical Journal, vol. 326, pp. 328-330, 2003.

[9] H. S. Barrows, "Problem-based, self-directed learning," American Medical Association, vol. 250, pp. 3077-3080, 1983.

[10] T. J. David, D. H. J. M. Dolmans, L. Patel, and C. P. M. van der Vleuten, "Problem-based learning as an alternative to lecturebased continuing medical education," Journal of the Royal Society of Medicine, vol. 28, pp. 372-380, 1998.

[11] H. Eshach and H. Bitterman, "From case-based reasoning to problem-based learning," Academic Medicine, vol. 78, pp. 491-496, 2003.

[12] M. Albanese and S. Mitchell, "Problem-based learning: A review of the literature on its outcomes and implementation issues," Academic Medicine, vol. 68, pp. 52-81, 1993.

[13] D. T. Vernon and R. L. Blake, "Does problem-based learning work? A metaanalysis of evaluative research," Academic Medicine, vol. 68, pp. 550-563, 1993.

[14] G. R. Norman and H. G. Schmidt, "Effectiveness of problembased learning curricula: Theory, practice and paper darts," Medical Education, vol. 34, pp. 721-728, 2000.

[15] G. T. Moore, S. D. Block, C. B. Style, and R. Mitchell, "The influence of the new pathway curriculum on Harvard medical students," Academic Medicine, vol. 69, pp. 983-989, 1994.

[16] H. Schmidt, L. Vermeulen, and H. van der Molen, "Long term effects of problem-based learning: a comparison of competencies acquired by graduates of a problem-based and a conventional medical school," Medical Education, vol. 40, pp. 562-567, 2006.

[17] J. Colliver, "Effectiveness of problem-based learning curricula: research and theory," Academic Medicine, vol. 75, pp. 259-266, 2000.

[18] M. Albanese, "Problem-based learning: why curricula are likely to show little effect on knowledge and clinical skills," Medical Education, vol. 34, pp. 729-738, 2001.

[19] G. C.-H. Koh, H. E. Khoo, M. L. Wong, and D. Koh, "The effects of problem-based learning during medical school on physician competency: a systematic review," Canadian Medical Association Journal, vol. 178, pp. 34-41, 2008.

[20] J. L. Bowen, "Educational strategies to promote clinical diagnostic reasoning," The New England Journal of Medicine, vol. 355, pp. 2217-2225, 2006.

[21] A. Holdsworth, K. Watty, and M. Davies, "Developing capstone learning experiences," Melbourne: Centre for the Study of Higher Education, 2009. http://www.cshe.unimelb.edu.au/ Accessed July 2010

[22] D. Steele, J. Medder, and P. Turner, "A comparison of learning outcomes and attitudes in student-versus faculty-led problembased learning: an experimental study," Medical Education, vol. 34, pp. 23-29, 2000.

[23] S. Kassab, M. Abu-Hijleh, Q. Al-Shboul, and H. Hamdy, "Student-led tutorials in problem-based learning: educational outcomes and student's perceptions," Medical Teacher, vol. 27, pp. 521-526, 2005.

[24] C. Roberts, M. Lawson, D. Newble, A. Self, and P. Chan, "The introduction of large class problem-based learning into an undergraduate medical curriculum: an evaluation," Medical Teacher, vol. 27, pp. 527-533, 2005.

[25] R. A. Tedman, R. Loudon, B. Wallace, and H. Pountney, "Integrating regular, on-line evaluation by students into the curriculum review process in an Australian medical program," International Journal of Emerging Technologies in Learning, vol. 4, pp. 59-66, 2009.

[26] M. Sheumack, "Curriculum Committee Submission to the Review of the MBBS Program School of Medicine, The University of Queensland," Brisbane, 2009. http://www2.som.uq.edu.au/som/ 
FutureStudents/MBBS/Review/Submissions/Review\%20submission \%20cww26266.pdf Accessed July 2009 (2009).

[27] T. Dornan, A. Scherpbier, N. King, and H. Boshuizen, "Clinical teachers and problem-based learning: a phenomenological study," Medical Education, vol. 39, pp. 163-170, 2005.

\section{AUTHORS}

H. Alexander was with the School of Medicine, Gold Coast campus, Griffith University QLD, 4222, AUSTRALIA
R. Tedman is with the School of Medicine, Gold Coast campus, Griffith University QLD, 4222, AUSTRALIA (email: r.tedman@griffith.edu.au )

B. Wallace is with the School of Medicine, Gold Coast campus, Griffith University QLD, 4222, AUSTRALIA (email: b.wallace@griffith.edu.au )

H. Pountney was with the School of Medicine, Gold Coast campus, Griffith University QLD, 4222, AUSTRALIA

Submitted November $15^{\text {th }}, 2010$. Published as resubmitted by the authors March $1^{\text {st }}, 2011$ 